\title{
PENGARUH MUTU PELAYANAN TERHADAP KEPUASAN PASIEN RAWAT INAP DI RUMAH SAKIT IZZA KARAWANG
}

\section{The Effect Of Quality Of Service On Inpatient Satisfaction At Izza Karawang Hospital}

\author{
Rahmawati Nur'aeni ${ }^{1}$, Asyiah Simanjorang ${ }^{2}$, Jamaluddin $^{3}$ \\ 1Mahasiswa Pascasarjana IKM Fakultas Kesehatan Masyarakat, Institut Kesehatan Helvetia, \\ Medan, Indonesia \\ 2Dosen IKM Fakultas Kesehatan Masyarakat, Institut Kesehatan Helvetia, Medan,Indonesia \\ 3Dosen IKM Fakultas Kesehatan Masyarakat, Institut Kesehatan Helvetia, Medan,Indonesia \\ *Penulis Korespondensi: rahmawati.nuraeni0229@yahoo.co.id ${ }^{1}$, \\ asyiahsimanjorang71@yahoo.com ${ }^{2}$, drjamaluddinmars@gmail.com ${ }^{3}$
}

\begin{abstract}
Abstrak
Pelayanan kesehatan merupakan hak setiap orang yang menjamin dalam UndangUndang Republik Indonesia. Kepuasan pasien salah satu indikator penting yang harus diperhatikan dalam pelayanan kesehatan. Tujuan penelitian ini untuk menganalisa hubungan Mutu Pelayanan Terhadap Kepuasan Pasien Rawat Inap di Rumah Sakit Umum Izza Karawang.

Penelitian ini adalah penelitian dengan pendekatan Cross Sectional Study. Populasi dalam penelitian ini pasien rawat inap di rumah sakit Izza Karawang. Sampel dari penelitian ini berjumlah 105 responden dengan cara pengambilan sampel penelitian menggunakan accidental sampling adalah pengambilan sampel yang dilakukan secara kebetulan.

Hasil penelitian menunjukkan bahwa terdapat hubungan antara mutu pelayanan dalam dimensi tangible memiliki hubungan terhadap kepuasan pasien rawat inap dengan nilai $\rho$ value sebesar $0,08<0,05$. Terdapat hubungan kepuasan pasien dengan dimensi : Reliability nilai $\rho$ value sebesar $0,00<0,05$; Responsiveness nilai $\rho$ value sebesar $0,08<0,05$; Assurance nilai $\rho$ value sebesar $0,00<0,05$; Empathy nilai $\rho$ value sebesar $0,00<0,05$. Secara serempak tangible, reliability, responsivenes, assurance, dan empathy memiliki hubungan signifikan terhadap kepuasan uji multivariate sebesar $0,00<0,05$. Variabel yang paling besar pengaruhnya terhadap kepuasan pasien rawat inap adalah variabel responsiveness (ketanggapan) yang mempunyai nilai p (Sig) $0,013<0,05$ dengan nilai EXP (B) atau disebut juga dengan nilai Odds Ratio (OR) 8,658 .

Kesimpulan dari penelitian dapat diketahui bahwa Tangible (wujudnyata), Reliability (kehandalan), Responsiveness (ketanggapan), Anssurance (jaminan) dan Empathy (empati) merupakan variabel yang paling mempengaruhi kepuasan pasien rawat inap. Disarankan kepada Rumah Sakit Izza Karawang dapat meningkatkan mutu pelayanan dapat memaksimalkan kepercayaan pasien dalam memanfaatkan pelayanan kesehatan.
\end{abstract}

Kata Kunci : Tangible (wujudnyata), $\quad$ Reliability (kehandalan),
Responsiveness (ketanggapan), Anssurance (jaminan), Empathy (empati), kepuasan 


\title{
Rahmawati Nur'aeni ${ }^{1}$, Asyiah Simanjorang ${ }^{2}$, Jamaluddin $^{3}$
}

\begin{abstract}
Health care is the right of every person who guarantees the Law of the Republic of Indonesia. Patient satisfaction is an important indicator that must be considered in health services. The purpose of this study was to analyze the relationship between Service Quality and Inpatient Satisfaction at Izza General Hospital, Karawang.

This research is a research with a cross sectional study approach. The population in this study were inpatients at the Izza Karawang hospital. The sample of this study amounted to 105 respondents by means of research sampling using accidental sampling is a sampling that was done by chance.

The results showed that there was a relationship between service quality in the tangible dimension and had a relationship with inpatient satisfaction with a $\rho$ value of $0.08<0.05$. There is a relationship between patient satisfaction and the dimensions: Reliability value $\rho$ value of $0.00<0.05$; The responsiveness of $\rho$ value is $0.08<0.05$; Assurance value of $\rho$ value of 0.00 $<0.05$; Empathy value of $\rho$ value of $0.00<0.05$. Simultaneously, tangible, reliability, responsiveness, assurance, and empathy have a significant relationship with the satisfaction of the multivariate test of $0.00<0.05$. The variable with the greatest influence on inpatient satisfaction is the responsiveness variable which has a p value (Sig) of $0.013<0.05$ with an EXP value (B) or also known as the Odds Ratio (OR) value of 8.658.

The conclusion of the study can be seen that Tangible (real form), Reliability (reliability), Responsiveness (responsiveness), Insurance (assurance) and Empathy (empathy) are the variables that most influence the satisfaction of inpatients. It is suggested that the Izza Karawang Hospital can improve the quality of service to maximize patient confidence in utilizing health services.
\end{abstract}

Keywords: Tangible (real form), Reliability (reliability), Responsiveness (responsiveness), Assurance (assurance), Empathy (empathy), satisfaction

\section{PENDAHULUAN}

Pelayanan kesehatan merupakan hak setiap orang yang menjamin dalam UndangUndang Republik Indonesia Nomor 36 Tahun 2009 tentang Kesehatan. Pemerintah bertanggung jawab untuk menyenggarakan pelayanan kesehatan yang aman, bermutu, merata dan terjangkau oleh masyarakat. Salah satu jenis pelayanan kesehatan yang diselenggarakan oleh pemerintah adalah kesehatan di rumah sakit (1).

Undang-undang Nomor 44 Tahun 2009 Tentang Rumah Sakit, dinyatakan bahwa rumah sakit merupakan institusi yang menyelenggarakan layanan kesehatan perorangan secara paripurna dalam bentuk layanan rawat inap, rawat jalan, dan gawat darurat. Sebagai pusat rujukan kesehatan utama, rumah sakit dituntut mampu memberikan pelayanan yang komprehensif bagi setiap pasiennya. Pelayanan kesehatan yang komprehensif adalah berbagai 
Journal of Healthcare Technology and Medicine Vol. 6 No. 2 Oktober 2020

Universitas Ubudiyah Indonesia

e-ISSN : 2615-109X

bentuk pelayanan yang diberikan kepada klien oleh suatu tim multi disiplin sesuai kebutuhan pasien. Rumah sakit diselenggarakan berdasarkan pada nilai kemanusiaan, profesionalitas, manfaat, keadilan, pemerataan, perlindungan pasien, serta mempunyai fungsi sosial (2).

Sebagai layanan kesehatan, kemampuan rumah sakit dalam memenuhi kebutuhan pasien dapat diukur dari tingkat kepuasan pasien. Kepuasan dimulai dari penerimaan terhadap pasien dari pertama kali datang, sampai pasien meninggalkan rumah sakit. Kemampuan rumah sakit dalam menyampaikan kualitas pelayanan kesehatan yang baik merupakan harapan bagi setiap masyarakat ketika datang untuk melakukan konsultasi atas permasalahan kesehatan yang sedang mereka rasakan (3).

Kepuasan pasien berhubungan dengan mutu pelayanan kesehatan. Jika suatu instansi kesehatan salah satunya puskesmas akan melakukan upaya peningkatan mutu pelayanan kesehatan, pengukuran tingkat kepuasan pasien harus dilakukan. Melalui pengukuran tersebut, dapat diketahui sejauh mana dimensi-dimensi mutu pelayanan kesehatan yang telah diselenggarakan dapat memenuhi harapan pasien.(7) Kepuasan pelanggan mempunyai tempat tersendiri dan merupakan hal yang sangat penting untuk bertahannya suatu rumah sakit. Kepuasan akan terjadi apabila harapan dari pelanggan dapat terpenuhi oleh pelayanan yang diberikan rumah sakit untuk dapat memanfaatkan kembali layanan kesehatan, oleh karena itu perlu diperhatikan dan dievaluasi terus menerus kepuasan dan harapan dari pelanggan serta diikuti dengan perbaikan-perbaikan pelayanan dan pengelolaan yang efektif serta efisien akan membuat rumah sakit mempunyai daya tahan dan daya saing yang tinggi untuk dapat menjaga kelangsungan rumah sakit dalam jangka pendek dan jangka panjang dengan membuat diferensiasi yang berbeda (8).

Kepuasan pasien merupakan aspek kunci perawatan kesehatan, dan telah ditunjukkan bahwa ada hubungan yang kuat antara perlakuan petugas kesehatan dan kepuasan pasien. Beberapa hasil penelitian menunjukkan data tentang tingkat kepuasan pasien di berbagai negara. Tingkat kepuasaaan pasien menurut peneliti sebelumnya di kenya terdapat 40,4\%, di india terdapat $34,4 \%$, sedangkan di indonesia menunjukkan angka kepuasan pasien 42,8\% (8).

Berdasarkan Institut Legatum mencatat, Indonesia masuk pada ranking 92 dalam daftar negara yang memiliki fasilitas pelayanan kesehatan terbaik dari 149 negara (9). Berbagai fakta menunjukkan adanya masalah serius dalam mutu pelayanan kesehatan di Indonesia. Hal ini disebabkan karena belum adanya sistem pengendali mutu yang terbaik yang dapat diterapkan. Pemahaman secara lebih mendalam tentang good governance merupakan salah satu upaya terhadap perwujudan pelayanan kesehatan yang lebih bermutu 
Journal of Healthcare Technology and Medicine Vol. 6 No. 2 Oktober 2020

Universitas Ubudiyah Indonesia

e-ISSN : 2615-109X

(9).

Dari hasil survei awal peneliti sendiri selama di ruang rawat inap Rumah Sakit Umum Izza Karawang, di dapati adanya pasien yang menyatakan kurang puas dengan pelayanan dilakukan di ruang perawatan rawat inap di Rumah Sakit. Selain itu, hasil survei awal yang dilakukan peneliti dengan cara tanya jawab kepada 6 pasien rawat inap. 2 dari 6 pasien rawat inap mengeluhkan sikap perawat yang terkesan kurang ramah dalam melayani pasien dan saat keluarga pasien ingin bertanya juga acuh tak acuh, pada saat jaga malam perawat tertidur dimana susah untuk di bangunkan keluarga pasien saat meminta bantuan bila infus habis atau pasien lagi keadaan sesak. Sikap perawat yang tidak tanggap tidak cepat melayani keluhan pasien, yang menyebabkan ketidakpuasan pasien terhadap pelayanan. Mengeluhkan jadwal pemberian obat atau injeksi obat yang tidak tepat jam sehingga pasien merasa kurang begitu nyaman. Saat dokter melakukan visite terhadap pasien sehingga pasien harus menunggu berjamjam kedatangan dokter untuk visite, dikarenakan dokter datang terlambat. Ruang rawat inap yang kurang bau amis juga mengganggu kenyamanan pasien yang menyebabkan ketidak puasan pasien terhadap pelayanan di rumah sakit.

\section{METODE PENELITIAN}

Menurut para ahli desain penelitian dapat diartikan sebagai suatu rencana kerja yang terstruktur dalam hal hubungan-hubungan antara variabel secara komprehensif sedemikian rupa agar hasil risetnya dapat memberikan jawaban atas pertanyaan-pertanyaan riset. Rencana tersebut mencakup hal-hal yang akan dilakukan priset, mulai dari membuat hipotesis dan implikasinya secara operasional sampai analisis akhir (41).

Penelitian ini menggunakan metode penelitian survai analitik. Survei analitik merupakan survei atau penelitian yang mencoba menggali bagaimana dan mengapa fenomena kesehatan itu terjadi (44). Dalam penelitian survei analitik ini, penelitian tidak dilakukan terhadap seluruh objek yang diteliti (populasi), tetapi hanya mengambil sebagian dari populasi tersebut (sampel). Rancangan penelitian yang digunakan adalah penelitian case control yaitu penelitian survey analitik yang menyangkut bagaimana faktor risiko dipelajari dengan menggunakan pendekatan restrospektive (44).

Penelitian ini adalah penelitian kuantitatif, menggunakan desain penelitian cross sectional dimana data variabel bebas dan variabel terikat diambil dalam waktu yang bersamaan (satu waktu pengumpulan data).Variabel mutu pelayanan dan kepuasan pasien rawat inap Rumah Sakit Izza Karawang dikumpulkan secara bersama pada satu kali pengumpulan data 
Journal of Healthcare Technology and Medicine Vol. 6 No. 2 Oktober 2020

Universitas Ubudiyah Indonesia

e-ISSN : 2615-109X

(44). Pendekatan ini digunakan untuk melihat hubungan antara variabel satu dengan variabel lainnya.

Lokasi penelitian dilakukan di Rumah akit Umum Izza Karawang, yang terletak di Jalan Raya Ciselang Cikampek Utara, Kotabaru Kabupaten Karawang, Jawa Barat, Indonesia.

Adapun waktu penelitian ini dilakukan pada bulan 20 Agustus 2020 sampai dengan 20 September 2020. Populasi adalah wilayah generalisasi yang terdiri atas; objek/subjek yang mempunyai kualitas dan karakteristik tertentu yang ditetapkan oleh peneliti untuk dipelajari dan kemudian ditarik kesimpulannya (46). Populasi dalam penelitian ini adalah seluruh pasien yang mendapat perawatan di ruang rawat inap di Rumah Sakit Umum Izza Karawang. Satu bulan pasien yang datang untuk rawat inap sebanyak 142 orang.

Teknik pengmbilan sampel dalam penelitian ini adalah accidental sampling. Accidental sampling yaitu pengambilan sampel yang dilakukan secara kebetulan, yaitu siapa saja yang secara kebetulan bertemu dengan peneliti dapat digunakan sebagai sampel (46). Dimana peneliti mengambil sampel berdasarkan pertimbangan tertentu yang dibuat oleh peneliti sendiri berdasarkan ciri dan sifat populasi yang sudah diketahui sebelumnya. Prosedur pengambilan sampling dalam penelitian ini dilakukan dengan cara accidental sampling (sampel yang ditemui pada saat penelitian).Uji validitas digunakan untuk mengukur sah atau tidaknya suatu kuesioner. Kuesioner dikatakan valid apabila pertanyaan pada kuesioner mampu mengungkapkan sesuatu yang akan diukur oleh kuesioner tersebut (48). Uji validitas akan dilakukan pada responden sebanyak 30 orang pasien Rumah Sakit Karya Husada Cikampek Karawang. Karena 30 responden sebagai sampel ujicoba untuk menguji validitas dan reliabilitas sebuah kuesioner kemudian mencari darimana asal angka 30, dan berapa sebenarnya jumlah yang tepat untuk menguji sebuah kuesioner. Uji validitas kuesioner dilakukan di Rumah Sakit Karya Husada Cikampek Karawang, butir kuesioner yang digunakan dilakukan uji validitas dengan nilai rtabel (0,361). Butir kuesioner signifikan apabila koefisien yang dihitung lebih besar dari dari koefisien dari $r_{\text {tabel }}(0,361)$ ( $r$ hitung $>r$ tabel).

Analisis univariat dilakukan pada tiap variabel dari hasil penelitian dan digunakan untuk mengetahui gambaran distribusi frekuensi dan persentase dari variabel bebas dan variabel terikat (49). Analisa ini digunakan untuk mengetahui pengaruh mutu pelayanan terhadap kepuasan pasien, dengan cara menghitung hasil dari pengisian kuesioner yang telah terkumpul dari para responden. Setelah data terkumpul, peneliti akan mengolah data dalam bentuk persentase dan data akan disajikan dalam bentuk tabel. 
Journal of Healthcare Technology and Medicine Vol. 6 No. 2 Oktober 2020

Universitas Ubudiyah Indonesia

e-ISSN : 2615-109X

Analisis bivariat adalah analisis yang dilakukan terhadap dua variabel yang diduga berhubungan atau berkorelasi (44). Analisa bivariat digunakan untuk menganalisis hubungan antara dua variabel yang meliputi variabel bebas dan variabel terikat (46). Analisis ini digunakan untuk menguji ada atau tidaknya perbedaan pengetahuan (variabel terikat) penanganan dismenorea sebelum dan sesudah diberikan penyuluhan (variabel bebas). Berdasarkan hasil uji normalitas data pada penelitian ini diketahui data berdistribusi normal sehingga untuk mengetahui adanya perbedaan pengetahuan sebelum dan sesudah penyuluhan dilakukan uji Paired Sample test.

Analisis multivariat dilakukan untuk melihat variabel independen yang paling berpengaruh terhadap variabel dependen. Analisis multivariat yang digunakan adalah regresi logistik model prediksi, dengan tingkat kepercayaan 95\% dan menggunakan metode menentukan odds rasio variabel kategorik polikontom dengan salah satu kategori menjadi pembanding dengan cara chi square.

\section{PENELITIAN DAN PEMBAHASAN}

\section{Hubungan tangible (wujud nyata) terhadap kepuasan pasien rawat inap di Rumah Sakit Izza Karawang.}

Hasil uji statistik chi square diperoleh nilai $\mathrm{p}=0,008<0,05$ yang artinya ada hubungan indikator tangible dengan kepuasan pasien. Hal ini menunjukkan bahwa responden yang mengatakan indikator tangible (wujud nyata) yang kurang puas sehingga akan berdampak kepada ketidakpuasan pasien rawat jalan yang diberikan Rumah Sakit Izza Karawang. Hasil penelitian di lapangan diperoleh bahwa responden yang mengatakan pasien yang merasakan tidak puas dengan tangible yang baik sebanyak 23 orang (21,9\%), kemudian yang puas dengan tangible yang baik sebanyak 80 orang $(76,2 \%)$, selanjutnya yang merasa tidak puas dengan tangible yang kurang baik 1 orang $(1,0 \%)$, dan puas dengan tangible yang kurang baik sebanyak 1 orang $(1,0 \%)$. Tangible merupakan bukti langsung yang dapat diarasakan oleh pasien tentang pelayanan yang didapatkan seperti sumber daya yang dimiliki baik peralatan yang dimiliki oleh rumah sakit ataupun petugas yang melakukan pelayanan dengan kerapian petugas baik dokter dan perawat yang ada rumah sakit tersebut.

Hasil penelitian ini sejalan dengan penelitian yang dilakukan oleh Djeinne Thresye Pangerapan. Hubungan Antara Mutu Pelayanan Dengan Kepuasan Pasien Di Poliklinik Penyakit Dalam Rumah Sakit Umum Gmim Pancaran Kasih Manado. Hasil penelitian menunjukkan uji chi square tangible (wujud nyata) 0,001<0.05. dengan kepuasan pasien di Poliklinik Penyakit dalam Rumah Sakit Umum GMIM Pancaran Kasih Manado (15). Selain itu juga didukung oleh penelitian yang dilakukan oleh Rismayanti. Pengaruh Mutu Pelayanan 
Journal of Healthcare Technology and Medicine Vol. 6 No. 2 Oktober 2020

Universitas Ubudiyah Indonesia

e-ISSN : 2615-109X

Terhadap Kepuasan Pasien Di Uptd Kesehatan Puskesmas Bojo Baru Kabupaten Barru. Hasil penelitian menunjukkan uji chi square variable tangible berpengaruh terhadap kepuasan pasien di UPTD Kesehatan Bojo Baru Kabupaten Barru.

Selanjutnya penelitian yang dilakukan oleh Ratna Purwaningrum. Analisis Mutu Pelayanan Terhadap Kepuasan Pasien Di Rumah Sakit Pertamina Bintang Amin Bandar Lampung Tahun 2018, Analisis Mutu Pelayanan Terhadap Kepuasan Pasien Di Rumah Sakit Pertamina Bintang Amin Bandar Lampung Tahun 2018. (15). Hasil penelitian menunjukkan uji chi square tangible berpengaruh terhadap kepuasan. Kemudian penelitian yang dilakukan oleh Andini Mentari Tarigan Pengaruh Mutu Pelayanan Kesehatan Terhadap Kepuasan Pasien Rawat Jalan Jantung Di Rumah Sakit Advent Medan Tahun 2018. Hasil penelitian menunjukkan uji chi square variable tangible p (Sig) $0.001<0.05 .(12)$. Penelitian ini sejalan dengan penelitian yang dilakukan oleh Nurhakiki Hasibuan. Hubungan Mutu Pelayanan Dokter Dengan Kepuasan Pasien Rawat Jalan Di Puskesmas Londut Kabupaten Labuhanbatu Utara. Hasil penelitian menunjukkan bahwa tangible berpengaruh terhadap kepuasan (21). Kemudian penelitian yang dilakukan oleh Grace Siama Juwit. Hubungan Mutu Pelayanan Dengan Kepuasan Pasien Rawat Inap Di Rumah Sakit Umum Daerah Tamiang Layang. Hasil penelitian menunjukkan uji chi square variable tangible p (Sig) $0.000<0.05(23)$.

Berdasarkan hasil penelitian penulis menyimpulkan bahwa tangible (wajud nyata) berhubungan dengan tingkat kepuasan pasien, dimana pasien rawat inap Rumah Sakit Izza berasumsi bahwa ruang pemeriksaan dan ruang tunggu yang bersih, rapi, dan nyaman serta memiliki alat medis yang cukup memadai, penampilan dokter maupun perawat bersih berhubungan positif dan memakai masker dengan tingkat kepuasan pasien rawat inap. Sehingga semakin baik wujud nyata rumah sakit sebagai penyedia pelayanan kesehatan yang dilihat oleh pasien, sehingga akan semakin baik pula tingkat kepuasan yang dirasakan oleh pasien. Hasil penelitian yang telah dilakukan juga masih terdapat sebagian pasien mengeluhkan seperti kurang nyamannya ruang tunggu pasien, ketersediaan kursi tunggu yang tidak memadai, hal tersebut dikarenakan ruang tunggu untuk pasien menunggu tidak terlalu besar. Disamping itu juga kebersihan dari setiap ruangan pemeriksaan masih dinilai kurang oleh pasien.

Hubungan reliability (kehandalan) terhadap kepuasan pasien rawat inap di Rumah Sakit

\section{Izza Karawang}

Hasil uji statistik chi square diperoleh nilai $\mathrm{p}=0,00<0,05$ yang artinya ada hubungan indikator reliability dengan kepuasan pasien. Hal ini menunjukkan bahwa responden yang 
Journal of Healthcare Technology and Medicine Vol. 6 No. 2 Oktober 2020

Universitas Ubudiyah Indonesia

e-ISSN : 2615-109X

mengatakan indikator reliability kurang puas cenderung berdampak kepada ketidakpuasan pasien tentang pelayanan rawat jalan jantung yang diberikan.

Hasil penelitian di lapangan diperoleh bahwa responden yang mengatakan reliability pasien yang merasakan tidak puas dengan reliability yang baik sebanyak 24 orang $(22,9 \%)$, kemudian yang puas dengan reliability yang baik sebanyak 81 orang $(77,1 \%)$, selanjutnya yang merasa puas dengan reliability yang kurang baik 0 orang $(0,0 \%)$, tidak puas dengan reliability yang baik sebanyak 0 orang $(0,0 \%)$. Reliability menyangkut tentang kehandalan baik petugas kesehatan maupun petugas administrasi. Kehandalan petugas dalam melayani pasien merupakan kunci awal pada saat pasien ingin mendapatkan pelayanan kesehatan seperti ketepatan waktu layanan dari pendaftaran sampai layanan pengobatan yang diberikan dokter.

Berdasarkan wawancara dengan pasien rawat inap berkaitan dengan mutu pelayanan dan kepuasan pasien, pelayanan yang diberikan perawat terhadap kepuasan pasien di ruang rawat inap sesuai dengan ilmu yang dimiliki perawat dalam melaksankaan tugas dalam merawat pasien dengan baik, menunjukkan kesiapan perawat dalam melakukan tindakan perawatan terhadap pasien. Namun ada juga pasien mengatakan masih belum maksimal, masih ada beberapa pasien mengeluh dengan perawatan yang tidak sesuai waktu yang telah ditentukan, sehingga tindakan yang dilakukan perawat sangat lama, dan kesiapan perawat belum maksimal akibat kurangnya pelatihan yang diberikan pihak rumah sakit, beberapa perawat tidak memberikan tegur sapa dan senyum serta salam terhadap pasien yang dirawatnya, sehingga pasien yang ada diruang rawat inap sering merasakan kurang puas terhadap mutu pelayanan

Hasil penelitian ini sejalan dengan penelitian yang dilakukan oleh Herman Harun. Analisis Faktor Yang Mempengaruhi Mutu Pelayanan Kesehatan Terhadap Kepuasan Pasien Di Puskesmas Rawat Inap Kabupaten Pasaman 2019. Hasil penelitian menunjukkan uji chi square $0.023<0,05$ Pasien Di Puskesmas Rawat Inap Kabupaten Pasaman 2019 (19). Selain itu juga didukung oleh penelitian yang dilakukan oleh Rismayanti. Pengaruh Mutu Pelayanan Terhadap Kepuasan Pasien Di UPTD Kesehatan Puskesmas Bojo Baru Kabupaten Barru. Hasil penelitian menunjukkan uji chi square variable reliability berpengaruh terhadap kepuasan pasien di UPTD Kesehatan Bojo Baru Kabupaten Barru (15).

Kemudian penelitian yang dilakukan oleh Andini Mentari Tarigan Pengaruh Mutu Pelayanan Kesehatan Terhadap Kepuasan Pasien Rawat Jalan Jantung Di Rumah Sakit Advent Medan Tahun 2018 (12). Hasil penelitian menunjukkan uji chi square variable reliability mempunyai nilai p (Sig) $0.000<0.05$. Selanjutnya penelitian yang dilakukan oleh Ratna Purwaningrum. Analisis Mutu Pelayanan Terhadap Kepuasan Pasien Di Rumah Sakit Pertamina 
Journal of Healthcare Technology and Medicine Vol. 6 No. 2 Oktober 2020

Universitas Ubudiyah Indonesia

e-ISSN : 2615-109X

Bintang Amin Bandar Lampung Tahun 2018, Analisis Mutu Pelayanan Terhadap Kepuasan Pasien Di Rumah Sakit Pertamina Bintang Amin Bandar Lampung Tahun 2018. Hasil penelitian menunjukkan uji chi square reliability berpengaruh terhadap kepuasan pasien (15).

Berdasarkan hasil penelitian yang dilakukan penulis menyimpulkan reliability (kehandalan) berhubungan dengan tingkat kepuasan pasien dan digunakan para pasien dalam mengevaluasi mutu pelayanan kesehatan. Jika suatu rumah sakit sebagai pelayanan kesehatan kurang handal, maka pasien tersebut merasa kurang puas bahkan tidak puas, ada beberapa pasien masih mengeluhkan keterlambatan jadwal pelayanan di loket pendaftaran khususnya peserta BPJS Kesehatan yang dapat mengakibatkan antrian pasien menumpuk dan membutuhkan waktu lama pasien untuk menunggu giliran.

\section{Hubungan responsiveness (ketanggpan) terhadap kepuasan pasien rawat inap di Rumah Sakit Izza Karawang}

Hasil uji statistik chi square diperoleh nilai $\mathrm{p}=0,008<0,05$ yang artinya ada hubungan indikator responsiveness dengan kepuasan pasien. Hal ini menunjukkan bahwa responden yang mengatakan indikator responsiveness yang kurang puas cenderung berdampak kepada ketidakpuasan pasien tentang pelayanan rawat jalan jantung yang diberikan.

Hasil penelitian di lapangan diperoleh bahwa responden yang mengatakan responsiveness pasien yang merasakan tidak puas dengan responsiveness yang baik sebanyak 6 orang $(5,7 \%)$, kemudian yang puas dengan responsiveness yang baik sebanyak 96 orang $(91,4 \%)$, dan yang sangat puas dengan responsiveness yang baik sebanyak 2 orang $(1,9 \%)$. Selanjutnya yang merasa puas dengan responsiveness yang kurang baik 0 orang $(0,0 \%)$, kemudian yang sudah puas dengan responsiveness yang kurang baik sebanyak 1 orang $(1,0 \%)$, dan yang tidak puas dengan responsiveness yang kurang baik 0 orang $(0,0 \%)$. Responsiveness merupakan respon atau kesigapan karyawan dalam membantu pelanggan dan memberikan pelayanan serta penanganan keluhan dengan cepat tanggap

Berdasarkan wawancara dengan pasien rawat inap terkait tentang mutu pelayanan dan kepuasan pasien, prosedur perawat dalam pelayanan menangani pasien khususnya pasien rawat inap ada beberapa pasien masih ada yang mengeluhkan kinerja dokter maupun perawat yang bekerja khususnya pada malam hari, dalam memberikan penanganan pasien ketika pasien membutuhkan penangan serius dalam keadaan biasa ataupun darurat. Pelayanan perawatan di ruang rawat inap menunjukkan belum maksimal yang berikan kepada pasien, seperti keterlambatan waktu dalam penangan pasien juga masih dirasakan, beberapa pasien misalnya 
Journal of Healthcare Technology and Medicine Vol. 6 No. 2 Oktober 2020

Universitas Ubudiyah Indonesia

e-ISSN : 2615-109X

dalam pemeriksaan rutinitas infus, belum maksimal dalam memperlakukan pasien di rawat inap, pelayanan yang tidak tepat waktu yang dilakukan perawat khususnya pada malam hari.

Hasil penelitian ini sejalan dengan penelitian yang dilakukan oleh Lisna Maulina (2019). Hubungan Mutu Pelayanan Kesehatan Dengan Kepuasan Pasien Peserta Bpjs Di Unit Rawat Inap Puskesmas Cibungbulang Kabupaten Bogor Tahun 2018. Hasil penelitian menunjukkan uji chi square $\mathrm{p}$-value $=0,000<0.05$. Selain itu juga didukung oleh penelitian yang dilakukan oleh Rismayanti. Pengaruh Mutu Pelayanan Terhadap Kepuasan Pasien Di UPTD Kesehatan Puskesmas Bojo Baru Kabupaten Barru. Hasil penelitian menunjukkan uji chi square variabel responsiveness berpengaruh terhadap kepuasan pasien di UPTD Kesehatan Bojo Baru Kabupaten Barru (15).

Selanjutnya penelitian yang dilakukan oleh Ratna Purwaningrum, Analisis Mutu Pelayanan Terhadap Kepuasan Pasien Di Rumah Sakit Pertamina Bintang Amin Bandar Lampung Tahun 2018, Analisis Mutu Pelayanan Terhadap Kepuasan Pasien Di Rumah Sakit Pertamina Bintang Amin Bandar Lampung Tahun 2018. Hasil penelitian menunjukkan uji chi square responsiveness berpengaruh terhadap kepuasan pasien (15)

Berdasarkan hasil penelitian yang telah dilakukan penulis menyimpulkan responsiveness (daya tanggap) berhubungan dengan tingkat kepuasan pasien, dimana pasien berasumsi bahwa responsiveness yang meliputi dokter menanyakan keluhan pasien, dokter menanggapi keluhan pasien, dokter memberikan kesempatan pasien untuk bertanya tentang penyakit yang diderita, dan dokter maupun perawat bersikap sopan dan ramah berhubungan positif dengan tingkat kepuasan pasien rawat inap Rumah Sakit Izza Karawang, maka semakin baik daya tanggap pelayanan kesehatan yang diberikan petugas kesehatan kepada pasien, sehingga akan meningkatkan tingkat kepuasan pasien yang berobat di Rumah Sakit Izza Karawang.

\section{Hubungan anssurance (jaminan) terhadap kepuasan pasien rawat inap di Rumah Sakit Izza Karawang}

Hasil uji statistik chi square diperoleh nilai $\mathrm{p}=0,000<0,05$ yang artinya ada hubungan indikator assurance dengan kepuasan pasien. Hal ini menunjukkan bahwa responden yang mengatakan indikator assurance yang kurang puas cenderung berdampak kepada ketidakpuasan pasien tentang pelayanan rawat jalan jantung yang diberikan.

Hasil penelitian di lapangan diperoleh bahwa responden yang mengatakan assurance pasien yang merasakan tidak puas dengan assurance yang baik sebanyak 24 orang $(22,9 \%)$, kemudian yang puas dengan assurance yang baik sebanyak 81 orang $(77,1 \%)$, selanjutnya yang 
Journal of Healthcare Technology and Medicine Vol. 6 No. 2 Oktober 2020

Universitas Ubudiyah Indonesia

e-ISSN : 2615-109X

merasa tidak puas dengan assurance yang kurang baik 0 orang $(0,0 \%)$, kemudian yang sudah puas dengan assurance yang baik sebanyak 0 orang $(0,0 \%)$. Jaminan merupakan pengetahuan dan kesopanan personel penyedia layanan serta kemampuan dalam membangun kepercayaan konsumen. Dimensi jaminan merupakan gabungan dari dimensi kompetensi, kesopanan, kredibilitas dan keamanan.

Berdasarkan wawancara dengan pasien rawat inap terkait dengan mutu pelayanan dan kepuasan pasien, pelayanan perawat di ruang rawat inap menunjukkan sikap dan kepedulian dokter dan perawat yang diberikan kepada pasien untuk memberikan informasi, keramahan, pelayanan yang diberikan kurang baik, sikap yang ditunjukkan pelayanan dokter dan perawat yang membuat pasien tidak nyaman dan kurang tanggap dalam menangani pasien ketika pasien membutuhkan perawatan medis di ruang rawat inap, khususnya pada malam hari kinerja perawat bahwa tingkat keseriusan perawat dalam menangani pasien ketika pasien sangat butuh bantuan kurang tanggap dan tidak cepat untuk segera melakukan tindakan yang ada di rawat inap. Penanganan dan keseriusan perawat maupun dokter terhadap tindakan yang akan dilakukan menunjukkan kinerja yang kurang tepat waktu, untuk penanganan pasien prioritas utama untuk keselamatan pasien menunjukkan keseriusan dokter maupun perawat dalam waktu yang tepat juga belum maksimal yang diberikan kepada pasien rawat inap khususnya perawat yang bertugas pada malam hari.

Penelitian ini sejalan dengan penelitian yang dilakukan oleh Nurhakiki Hasibuan (21). Hubungan Mutu Pelayanan Dokter Dengan Kepuasan Pasien Rawat Jalan Di Puskesmas Londut Kabupaten Labuhanbatu Utara. Hasil penelitian menunjukkan bahwa assurance berpengaruh terhadap kepuasan. Penelitian ini sejalan dengan penelitian yang dilakukan oleh Grace Siama Juwit. Hubungan Mutu Pelayanan Dengan Kepuasan Pasien Rawat Inap Di Rumah Sakit Umum Daerah Tamiang Layang. Hasil penelitian menunjukkan uji chi square variable assurance p (Sig) $0.000<0.05(23)$.

Berdasarkan hasil penelitian yang dilakukan penulis menyimpulkan bahwa assurance (jaminan) berhubungan dengan tingkat kepuasan pasien, dimana pasien memiliki asumsi bahwa Rumah Sakit Izza Karawang sebagai penyedia pelayanan harus memberikan informasi yang jelas dan akurat tentang apa, siapa, kapan, dimana dan bagaimana ketepatan pelayanan kesehatan diberikan. Apabila jaminan pelayanan baik maka akan berpengaruh terhadap tingkat kepuasan pasien yang berobat pada Rumah Sakit Izza Karawang.

Hubungan empathy (empati) terhadap kepuasan pasien rawat inap di Rumah Sakit Izza Karawang. 
Journal of Healthcare Technology and Medicine Vol. 6 No. 2 Oktober 2020

Universitas Ubudiyah Indonesia

e-ISSN : 2615-109X

Hasil uji statistik chi square diperoleh nilai $\mathrm{p}=0,000<0,05$ yang artinya ada hubungan indikator empathy dengan kepuasan pasien. Hal ini menunjukkan bahwa responden yang mengatakan indikator empathy yang kurang puas cenderung berdampak kepada ketidakpuasan pasien tentang pelayanan rawat jalan jantung yang diberikan.

Hasil penelitian di lapangan diperoleh bahwa responden yang mengatakan empathy pasien yang merasakan tidak puas dengan empathy yang kurang baik sebanyak 9 orang (8.57\%), kemudian yang tidak puas dengan empathy yang merasa baik sebanyak 15 orang (14.28\%), selanjutnya yang merasa puas dengan empathy yang kurang baik 25 orang (23.80\%), kemudian yang sudah puas dengan empathy yang baik sebanyak 56 orang (53.33\%). Empathy merupakan perhatian tenaga medis ketika menanyakan kondisi perkembangan pasien kelancaran pengurusan pengobatan pasien seperti administrasi sampai pelayanan farmasi.

Berdasarkan wawancara dengan pasien rawat inap terkait mutu pelayanan dan kepuasan pasien, pelayanan dokter dan perawat terhadap pasien, bukti empati dokter terhadap pasien bahwa pasien mengeluh tentang dokter dimana dokter yang mendiagnosa penyakit yang di derita pasien sudah maksimal, hal ini menunjukkan bahwa dokter dan perawat terlihat dari kinerja dokter, tingkat keseriusan perawat dengan pelayanan di ruang rawat inap. Namun ada juga beberapa pasien mengemukakan bahwatidak sesuai dengan pada yang diperiksa perawat terhadap penyakit yang di derita, pasien sebagian pasien mengeluh kurang sikap perhatian dokter terhadap tindakan yang belum maksimal dilakukan untuk menangani masalah penyakit di derita pasien.

Hasil penelitian menunjukkan uji chi square $\mathrm{p}$-value $=0,000<0.05$. Selain itu juga didukung oleh penelitian yang dilakukan oleh Rismayanti. Pengaruh Mutu Pelayanan Terhadap Kepuasan Pasien Di UPTD Kesehatan Puskesmas Bojo Baru Kabupaten Barru. Hasil penelitian menunjukkan uji chi square variable empathy berpengaruh terhadap kepuasan pasien di UPTD Kesehatan Bojo Baru Kabupaten Barru.

Berdasarkan hasil penelitian pernulis menryimpulkan empathy (empati) berhubungan dengan tingkat kepuasan pasien rawat inap di Rumah Sakit,Izza Karawang dimana para pasien berasumsi bahwa pelayanan yang diberikan oleh dokter maupun perawat dapat menenangkan rasa cemas pasien, mampu menangani keluhan pasien dengan baik dan memberikan saran kepada pasien, serta meluangkan waktu untuk dapat berkonsultasi secara pribadi mengenai penyakit pasiennya. 
Journal of Healthcare Technology and Medicine Vol. 6 No. 2 Oktober 2020

Universitas Ubudiyah Indonesia

e-ISSN : 2615-109X

\section{Hubungan tangible, reliability, responsiveness, assurance dan empathy terhadap}

\section{kepuasan}

Hasil penelitian secara secara bersama-sama variable tangible, reliability, responsiveness, assurance dan empathy mempunyai pengaruh terhadap variable kepuasan.

Hasil penelitian ini didukung dengan penelitian yang dilakukan oleh Joyce Yulianti Silalahi.

Analisis Mutu Pelayanan Perawat Terhadap Kepuasan Pasien Rawat Inap Kelas III di Rumah Sakit Advent Medan Tahun 2018. Hasil analisis multivariat menunjukkan variabel pasien terhindar dari bahaya $(\mathrm{p}=0.009 ; \operatorname{Exp}(\mathrm{B}) 76.851)$ dan pasien merasa nyaman $(\mathrm{p}=0.035 ; \operatorname{Exp}(\mathrm{B})$ 15.308) berpengaruh signifikan terhadap kepuasan pasien rawat inap kelas III Rumah Sakit Advent Medan (16). Selanjutnya penelitian yang dilakukan oleh Siti Kurnia Widi Hastuti Hubungan Mutu Pelayanan dengan Kepuasan Pasien Peserta BPJS di Rumah Sakit Umum Daerah Yogyakarta. Hasil penelitian menunjukkan bahwa Nilai p dari semua variabel dimensi mutu pelayanan lebih kecil dari nilai $\alpha(0,000)(17)$.

Penelitian ini juga sejalan dengan penelitian yang dilakukan oleh Aisyah Lahdji.

Faktor Faktor yang Mempengaruhi Mutu Pelayanan Kesehatan terhadap Kepuasan Pasien BPJS di Klinik Penyakit Dalam RSUD Sunan Kalijaga Demak Periode Mei-Oktober 2015. Penelitian yang diperoleh didapatkan nilai $\mathrm{p}=0,000(<0,05)$ sehingga dapat disimpulkan bahwa ada pengaruh mutu pelayanan kesehatan BPJS terhadap kepuasan pasien di RSUD Sunan Kalijaga Demak (18).

\section{KESIMPULAN DAN SARAN}

Ada hubungan tangible (wujud nyata) terhadap kepuasan pasien rawat inap Rumah Sakit Izza Karawang. Ada hubungan reliability terhadap kepuasan pasien, pasien rawat inap Rumah Sakit Izza Karawang. Ada hubungan responsiveness terhadap kepuasan pasien rawat inap Rumah Sakit Izza Karawang. Ada hubungan assurance terhadap kepuasan pasien rawat inap Rumah Sakit Izza Karawang. Ada hubungan empathy berpengaruh terhadap kepuasan pasien rawat inap Rumah Sakit Izza Karawang. Variabel yang paling besar pengaruhnya terhadap kepuasan pasien rawat inap adalah variabel responsiveness (ketanggapan) yang mempunyai nilai $\mathrm{p}$ (Sig) $0,013<0,05$ dengan nilai EXP (B) atau disebut juga dengan nilai Odds Ratio (OR) 8,658 yang artinya indikator responsiveness yang kurang puas atau rendah lebih berisiko terhadap ketidakpuasan pasien terhadap mutu pelayanan rawat jalan. Hendaknya rumah sakit Izza Karawang agar senantiasa meningkatkan pelayanan guna tercapainya kepuasan pasien, khusunya pada pasien rawat inap.hal ini bisa dilakukan dengan lebih memperhatikan terhadap kebutuhan dan keinginan pasien, peningkatan fasilitas sarana dan prasarana, jaminan rasa aman, 
Journal of Healthcare Technology and Medicine Vol. 6 No. 2 Oktober 2020

Universitas Ubudiyah Indonesia

e-ISSN : 2615-109X

nyaman, dan kepercayaan serta pelayanan yang dijanjikan secara cepat, akurat dan pasti sehingga akan meningkatkan kepuasan pasien.

\section{DAFTAR PUSTAKA}

Afrilianti. Kepuasan Pasien Terhadap Mutu Pelayanan Rawat Inap Berdasarkan Metode Serqual di RSUD Cilegon Tahun 2014. Jakarta: Universitas Islam Negeri Syarif Hidayahtullah Jakarta; 2016.

Departemen Kesehatan RI. Peraturan Menteri Kesehatan Republik Indonesia. Jakarta: Departemen Kesehatan RI; 2009.

Kurniati. Kepuasan Pasien Rawat Inap Lontara Kelas III Terhadap Pelayanan Kesehatan di Rumah Sakit Wahidin Sudirohusodo Makasar. Makasar: Universitas Hasanuddin; 2013.

Setiawan I. Tingkat Kepuasaan Pasien Terhadap Pelayanan Perawat di Unit Gawat Darurat di Rumah Sakit Haji Jakarta. Jakarta; 2016.

Ilahi PP. Hubungan Kepuasan Pasien Pengguna BPJS Terhadap Kualitas Pelayanan Kesehatan di Puskesmas Nagrak Sukabumi. Ketiga. Jakarta: Fakultas Kedokteran dan IlmuKesehatan UIN Syarif Hidayatullah.; 2016.

Munsil K. Analisis Kepuasan Pasien Terhadap Mutu Pelayanan Kesehatan Pada Poli Jantung dengan Metode IPA di RSUD Bahteramas Provinsi Sulawesi Tenggara. Universitas Halu Oleo; 2018.

Gesti Weningtyas. Negara Dengan Fasilitas Kesehatan Terbaik di Dunia. https://cekaja.com. 2019;1(1).

Azwar. Pengantar Administrasi Kesehatan. Jakarta: Bina Rupa Aksara; 2009.

Heni Rohaeni; Ima Rahayu. Pengaruh Kualitas Pelayanana Terhadap Kepuasan Pasien Pada Rumah Sakit Khusus Gigi dan Mulut Kota Bandung. http://jurnal.untirta.ac.id. 2017;

Tarigan AM. Pengaruh Mutu Pelayanan Kesehatan Terhadap Kepuasan Pasien Rawat Jalan di RS Advent Medan. http://ejournal. helvetia.ac.id ejournal.helvetia.ac.id. 2018;

Bata RG. Pengaruh Mutu Pelayanan Terhadap Kepuasan Pasien Di UPTD Kesehatan Puskesmas Bojo Baru Kabupaten Barru. https://stiemkop.ac.id. 2018;

Ratna Purwaningrum. Analisis Mutu Pelayanan Terhadap Kepuasan Pasien di Rumah Sakit Pertamina Bintang Amin Bandar Lampung. https://ejornal.malahayati.ac.id. 2018;

Djeinne Thresye Pangerapan. Hub Antara Mutu Pelayanan Dengan Kepuasan Pasien Di

Poliklin Penyakit Dalam Rumah Sakit Umum Gmim Pancar Kasih Manad J Kedokt Klin. 2018;2(1).

Silalahi JY. Analisis Mutu Pelayanan Perawat Terhadap Kepuasan Pasien Rawat Inap Kelas III di Rumah Sakit Advent Medan Tahun 2018. E-Journal. 2019;Vol. 1(No. 1).

Hastuti SKW. Hubungan Mutu Pelayanan dengan Kepuasan Pasien Peserta BPJS di Rumah Sakit Umum Daerah Yogyakarta. J Fak Kesehat Masy. 2017;Vol. 11(No. 2).

Lahdji A. Faktor Faktor yang Mempengaruhi Mutu Pelayanan Kesehatan terhadap

Kepuasan Pasien BPJS di Klinik Penyakit Dalam RSUD Sunan Kalijaga Demak Periode MeiOktober 2015. E-Journal. 2016; Vol. 3(No. 1).

Harun H. Analisis Faktor Yang Mempengaruhi Mutu Pelayanan Kesehatan Terhadap Kepuasan Pasien Di Puskesmas Rawat Inap Kabupaten Pasaman 2019. E-Journal. 2019; Vol. 4(No. 3). 
Journal of Healthcare Technology and Medicine Vol. 6 No. 2 Oktober 2020

Universitas Ubudiyah Indonesia

e-ISSN : 2615-109X

Maulina L. Hubungan Mutu Pelayanan Kesehatan Dengan Kepuasan Pasien Peserta Bpjs Di Unit Rawat Inap Puskesmas Cibungbulang Kabupaten Bogor Tahun 2018. EJournal. 2019; Vol. 2(No. 2).

Hasibuan N. Hubungan Mutu Pelayanan Dokter Dengan Kepuasan Pasien Rawat Jalan Di Puskesmas Londut Kabupaten Labuhanbatu Utara. E-Journal. 2018;Vol. 3(No. 1).

Burhanuddin N. Hubungan Mutu Pelayanan Kesehatan Dengan Kepuasan Pasien RSUD Syekh Yusuf Gowa. E-Journal. 2016;Vol. 4(No. 1).

Juwit GS. Hubungan Mutu Pelayanan Dengan Kepuasan Pasien Rawat Inap Di Rumah Sakit Umum Daerah Tamiang Layang. E-Journal. 2017; Vol. 7(No. 2).

Essiam JO. Service Quality and Patients Satisfaction with Healthcare Delivery: Empirical Evidence from Patients of the Out Patient Department of a Public University Hospital in Ghana. E-Journal. 2013;Vol. 5(No. 2).

Listiawaty R. The Influence of Service Quality Perseption Toward Inpatient Satisfaction At Mayjen H.A Thalib Hospital Kerinci 2016. E-Journal. 2017;Vol. 1(No.

2).

Bustami. Penjaminan Mutu Pelayanan Kesehatan \& Akseptabilitasnya. Jakarta: Erlangga; 2011.

Satrinegara. Organisasi Dan Manajemen Pelayanan Kesehatan: Teori dan Aplikasi Dalam Pelayanan Puskesmas dan Rumah Sakit. Jakarta: Salemba Medika; 2014.

Herlambang S. Manajemen Pelayanan Kesehatan Rumah Sakit. Yogyakarta: Gosyen Publishing; 2016.

Pohan. Jaminan Mutu Pelayanan Kesehatan, Dasar-dasar Pengertian dan Penerapan. Jakarta: Buku Kedokteran EGC; 2011.

Parasuraman. A Conceptual Model of Service Quality and ItsImplication forr Future Reaserch. Serv Qual J. 2016; Vol. 6(No. 1).

Muninjaya. Manajemen Mutu Pelayanan Kesehatan. Jakarta: EGC; 2014.

Pohan SI. Jaminan Mutu Pelayanan Kesehatan. Jakarta: EGC; 2007.

Nursalam. Manajemen Keperawatan: Aplikasi Dalam Praktik Keperawatan

Profesional. Jakarta: Salemba Medika; 2014.

Mamik. Organisasi dan Manajemen Pelayanan Kesehatan dan Kebidanan. Surabaya: Prins Media; 2010.

Hafizurrachman. Pengukuran Kepuasan Suatu Institusi Kesehatan. Majalah Kedokteran Indonesia. 2004;

Lupiyoadi R. Manajemen Pemasaran Jasa. Jakarta: Salemba Empat; 2014.

Irawan H. Sepuluh Prinsip Kepuasan Pelanggan Paradigma Baru Merebut Hati Pelanggan Untuk Menenangkan Pelanggan. Jakarta: Elex Media Komputindo; 2004.

Suryawati Chriswardani, Dharminto, Zahroh S. Penyusunan Indikator Kepuasan Pasien Rawat Inap Rumah Sakit di Provinsi Jawa Tengah. J Manaj Pelayanan Kesehat. 2006; Vol. 9(No. 12).

Sabarguna. Quality Assurance Pelayanan Rumah Sakit. Yogyakarta: Konsorsium Rumah Sakit Islam Jateng; 2004.

Sari ID. Hubungan Kualitas Pelayanan dan Karakteristik Pasien Dengan Loyalitas Pasien Umum di Rumah Sakit Umum Daerah Solok Sumatera Barat. Padang; 2012.

Umar H. Metode Penelitian Untuk Skripsi dan Tesis Bisnis. Jakarta: PT Raja Grafindo Persada; 2007.

Azwar. Menjaga Mutu Pelayanan Kesehatan. Jakarta: Sinar Harapan; 2010. 
Journal of Healthcare Technology and Medicine Vol. 6 No. 2 Oktober 2020

Universitas Ubudiyah Indonesia

e-ISSN : 2615-109X

Gafar Hartatiyanto. Permenkes No. 56 Tahun 2014 Tentang Klasifikasi Rumah Sakit. www.slideshare.net. 2014;

Notoatmodjo S. Metode Penelitian Kesehatan. Jakarta: Rineka Cipta; 2010.

Arikunto S. Prosedur Penelitian Suatu Pendekatan Praktik. Jakarta: Rineka Cipta; 2013.

Sugiyono. Metode Penelitian Kuantitatif, Kualitatif dan R \& D. Bandung: Alfabeta; 2016.

Nursalam. Konsep dan Penerapan Metodologi Penelitian Ilmu Keperawatan Pedoman Skripsi, Tesis, dan Instrumen Penelitian Keperawatan. Jakarta: Salemba Medika; 2011.

Ghozali I. Aplikasi Analisis Multivariate dengan Program IBM SPSS. 23. Semarang: BPFE Universitas Diponegoro; 2016.

Notoatmodjo S. Promosi Kesehatan Teori dan Aplikasi. Jakarta: Rineka Cipta; 2005.

Kusumawati SSU\& B. Faktor-Faktor Yang Memengaruhi Minat Penggunaan E-Money (Studi Pada Mahasiswa STIE Ahmad Dahlan Jakarta). E-Journal. 2017;Vol. 7(No. 3). 